\title{
Potensi Ekstrak Buah Buni (Antidesma bunius (L) Spreng) Sebagai Inhibitor Enzim $\alpha$-Glukosidase
}

\author{
La Hamidu $^{1 *}$, Partomuan Simanjuntak ${ }^{2}$, Rizna Triana Dewi ${ }^{3}$ \\ ${ }^{1}$ Fakultas Farmasi, Universitas Pancasila, Jakarta Selatan \\ ${ }^{2}$ Puslit Bioteknologi, LIPI, Bogor \\ ${ }^{3}$ Puslit Kimia, LIPI, Tangerang Selatan
}

\begin{tabular}{|c|c|}
\hline Article info & Abstract \\
\hline History & Diabetes mellitus is still a global health problem that continues to increase \\
\hline Submission: $21-01-2020$ & rapidly and become one of the major metabolic diseases throughout the \\
\hline Review: $15-02-2020$ & world. This study aims to determine the potential of Buni fruit as an $\alpha-$ \\
\hline Accepted: $22-02-2020$ & glucosidase inhibitor. $\alpha$-glucosidase inhibition test is carried out on a blank \\
\hline $\begin{array}{l}\text { "Email: } \\
\text { hamidun30@gmail.com }\end{array}$ & $\begin{array}{l}\text { solution (test solution without sample/standard), acarbose solution as a } \\
\text { comparison standard and samples are carried out in accordance with the }\end{array}$ \\
\hline DOI: $10.33096 /$ jffi.v7i1.598 & $\begin{array}{l}\text { optimization conditions obtained. The rendemen percent of green and red } \\
\text { buni fruit extract yields are } 6.35 \% \text { and } 3.09 \% \text {, respectively. The results of } \\
\text { the identification of secondary metabolites using TLC showed that green }\end{array}$ \\
\hline 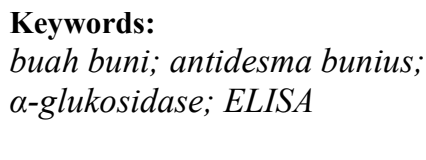 & $\begin{array}{l}\text { and red buni fruit extract contains flavonoid, phenolic and alkaloid } \\
\text { compounds. The results of the } \alpha \text {-glucosidase enzyme inhibition test showed } \\
\text { that the red buni fruit extract had the highest activity compared to green } \\
\text { buni fruit extract with an } I C_{50} \text { value of } 85.27 \text { ppm. }\end{array}$ \\
\hline
\end{tabular}

\section{Pendahuluan}

Diabetes melitus (DM) masih menjadi masalah kesehatan global yang terus meningkat pesat (Sunarwidhi, Sudarsono and Nugroho, 2014). Diabetes melitus adalah salah satu penyakit metabolik utama diseluruh dunia (Şendoğdu et al., 2006; Zatalia and Sanusi, 2013) dengan estimasi 143 juta orang menderita penyakit ini. Jumlah ini mungkin dua kali lipat pada tahun 2030 (Oyenihi et al., 2014). Riset Kesehatan Dasar (Riskesdas) pada tahun 2013 (Badan Penelitian dan Pengembangan Kesehatan, 2013) mengungkapkan lebih dari sepertiga penduduk Indonesia $(36,6 \%)$ mengalami glukosa darah puasa (GDP) terganggu dan toleransi glukosa terganggu (TGT) $(29,9)$ pada umur $\geq 15$.

Diabetes melitus adalah kelompok penyakit yang menghasilkan banyak etiologi ganda dari kerusakan sekresi insulin, kerja insulin atau keduanya (Ayepola, Brooks and Oguntibeju, no date; Goldenberg and Punthakee, 2013), dan/atau resistensi insulin (Zatalia and Sanusi, 2013). Defisiensi pada akhirnya menyebabkan hiperglikemia kronik (kadar glukosa dalam darah sangat tinggi) (Zatalia and Sanusi, 2013), gangguan karbohidrat, lemak (lipid), dan metabolism protein (Ayepola, Brooks and Oguntibeju, no date; Nugroho, 2006; Bisht, Shradha; Sisodia, 2010; Oyenihi et al., 2014).

Hasil penelitian Samappito dan Butkhup (Samappito and Butkhup, 2008) terhadap varietas Mao Luang atau buah Buni (Antidesma bunius L. Spreng) menunjukkan bahwa tanaman ini adalah jenis tanaman medis dimana banyak penduduk desa di Timur Laut Thailand menggunakan jus buahbuahan matang untuk menyembuhkan masalah kesehatan mereka pada diabetes, disentri, gangguan pencernaan dan sembelit. Butkhup dan Samappito (Butkhup and Samappito, 2011) juga melaporkan bahwa buah Buni (A. bunius) mengandung beberapa senyawa polifenol dengan sifat antioksidan kuat dan memiliki kandungan flavonoid total pada masingmasing ekstrak $n$-heksan, etil asetat dan metanol dengan ekstraksi bertingkat sebesar 10,72\%, 7,9\%, dan 3,56\% (Hamidu, Ahmad and Najib, 2018). Jumlah senyawa polifenol secara signifikan berubah selama proses perkembangan dan pematangan. Procyanidin B2, procyanidin B1, (+)-katekin, (-)epikatekin, rutin dan tran-resveratrol sebagai senyawa polifenol utama meningkat, tetapi asam fenolik lainnya seperti asam galat, kafeat, dan asam alegat secara signifikan menurun selama perkembangan dan pematangan. Ekstrak metanol buah $A$. bunius yang tumbuh di Manipur, India, juga menunjukkan aktivitas antioksidan yang tinggi, dengan nilai rata-rata $\mathrm{IC}_{50} 100,08 \mu \mathrm{g} / \mathrm{mL}$, bila dibandingkan dengan buah lainnya (Butkhup and Samappito, 2011).

Indonesia sendiri memiliki banyak keanekaragaman spesies tumbuhan yang salah satunya adalah buah Buni (A. bunius). Buah Buni mudah ditemukan di daerah Sulawesi karena merupakan salah satu buah yang biasa dikonsumsi oleh masyarakat, sehingga sangat memungkinkan untuk diteliti dan dikembangkan sebagai bahan baku obat antidiabetes sehingga perlu dilakukan 
penelitian tentang potensi buah Buni sebagai penghambat enzim $\alpha$-glukosidase.

\section{Metode Penelitian \\ II.1 Pengambilan dan Pengolahan sampel}

Sampel buah Buni (A. bunius) yang digunakan adalah buah buni yang berwarna hijau (muda) dan yang berwarna merah (matang) yang diambil di Kabupaten Enrekang. Sampel kemudian dibersihkan dari kotoran yang melekat dengan menggunakan air mengalir lalu dikeringkan dengan cara diangin-anginkan. Setelah kering, sampel diserbukkan, kemudian diekstraksi dengan metode maserasi.

\section{II.2 Ekstraksi Sampel}

Serbuk buah Buni hijau dan merah ditimbang masing-masing 450 dan 1150 gram kemudian dimasukkan dalam wadah maserasi. Maserasi dengan menggunakan etanol $96 \%$ selama 24 jam. Selanjutnya, remaserasi residu dengan pelarut yang sama sebanyak 3 kali dan ekstrak cair yang diperoleh dicampur dengan ekstrak cair sebelumnya. Ekstrak cair dikumpulkan kemudian dipekatkan dengan rotary vacuum evaporator hingga diperoleh ekstrak etanol kental.

\section{II.3 Identifikasi Senyawa Kimia}

Identifikasi senyawa kimia pada Ekstrak Buah Buni (EBB) menggunakan metode Kromatografi Lapis Tipis (KLT). Fase diam yang digunakan adalah silika gel 60 F254 dan fase geraknya adalah $n$-heksan:etil asetat (2:8). Senyawa kimia yang di identifikasi adalah senyawa golongan flavonoid $\left(\mathrm{AlCl}_{3}\right)$, fenolik $\left(\mathrm{FeCl}_{3}\right.$ dan FolinCiocalteu), alkaloid (Dragendorf), dan saponin (Vanilin asam sulfat).

\section{II.4 Uji Penghambatan $\alpha$-glukosidase}

Uji penghambatan $\alpha$-glukosidase dilakukan terhadap larutan blanko (larutan uji tanpa sampel/standar), larutan akarbose (Glucobay ${ }^{\circledR}$ ) sebagai pembanding, dan sampel yang dilakukan sesuai dengan kondisi optimasi yang diperoleh. Setiap larutan uji memiliki larutan kontrol masingmasing, yaitu larutan uji dengan penambahan natrium karbonat terlebih dahulu.

Standar pembanding dan sampel ditimbang dan dilarutkan dengan dapar fosfat $\mathrm{pH}$ 6,8. Sampel yang tidak larut dengan dapar fosfat dilarutkan terlebih dahulu dengan DMSO maksimal $10 \%$. Kemudian larutan standar dan sampel diencerkan ke dalam beberapa konsentrasi.

Sebanyak $30 \mu \mathrm{L}$ larutan standard dan sampel masing-masing ditambahkan $17 \mu \mathrm{L}$ substrat $p$ NPG 5 mM. Kemudian larutan diinkubasi selama 5 menit pada suhu $37^{\circ} \mathrm{C}$ dan ditambahkan $17 \mu \mathrm{L}$ larutan $\alpha$-glukosidase 0,15 Unit/mL. Larutan diinkubasi kembali pada suhu $37^{\circ} \mathrm{C}$ selama 15 menit. Setelah itu, ditambahkan $100 \mathrm{~mL}$ natrium karbonat $267 \mathrm{mM}$. Larutan diukur absorbansinya dengan microplate reader pada $\lambda 405 \mathrm{~nm}$.

Prosedur yang sama dilakukan untuk uji kontrol, tetapi terdapat perbedaan pada saat setelah inkubasi pertama, yaitu $100 \mu \mathrm{L}$ natrium karbonat $267 \mathrm{mM}$ ditambahkan terlebih dahulu dan $17 \mu \mathrm{L}$ larutan $\alpha$-glukosidase $0,15 \mathrm{Unit} / \mathrm{mL}$ ditambahkan setelah inkubasi kedua. Kemudian larutan diukur absorbansinya dengan microplate reader pada $\lambda 405$ nm.

\section{Hasil Dan Pembahasan}

Pada penelitian ini menggunakan tumbuhan buni (A. bunius) yang diambil di kabupaten Enrekang, Sulawesi Selatan. Simplisia yang digunakan berupa buah yang berwarna hijau dan merah dengan berat masing-masing 450 dan $1150 \mathrm{~g}$.

Metode ekstraksi yang digunakan pada penelitian ini adalah maserasi dengan menggunakan pelarut etanol $96 \%$. Maserasi merupakan metode ekstraksi yang tidak menggunakan pemanasan dalam prosesnya, sehingga lebih aman dalam menarik senyawa yang stabil dan tidak stabil terhadap pemanasan pada suhu tinggi. Senyawa yang ingin diisolasi dalam penelitian ini adalah yang dapat menghambat enzim $\alpha$-glukosidase seperti terpenoid, fenolik (Van Quan et al., 2019), alkaloid, quinin, flavonoid, fenol, dan fenilpropanoid (Yin et al., 2014), sehingga penggunaan pelarut etanol $96 \%$ sangat efektif dalam menarik senyawa-senyawa tersebut. Metode penguapan menggunakan alat rotavapor dengan suhu $40^{\circ} \mathrm{C}$ dan evaporasi sederhana. Ekstrak yang diperoleh dan persen rendemen masing-masing ekstrak ditampilkan pada Tabel 1.

Tabel 1. Persen Rendamen Ekstrak Buah Buni (EBB)

\begin{tabular}{lllll}
\hline No & Buah Buni & Berat Serbuk (g) & Berat Ekstrak (g) & Rendemen Ekstrak (\%) \\
\hline 1 & Hijau & 450 & 28,59 & 6,35 \\
2 & Merah & 1150 & 35,48 & 3,09 \\
\hline
\end{tabular}

Berdasarkan Tabel 1, EBB hijau memiliki persen rendemen ekstrak paling tinggi diikuti EBB merah. Hal ini menunjukkan bahwa buah buni yang berwarna hijau memiliki kandungan metabolit sekunder yang paling tinggi dibandingankan dengan buah buni yang masih berwarna merah.
EBB selanjutnya di identfikasi kandungan senyawa metabolit sekundernya secara kromatografi lapis tipis dengan menggunakan fase gerak $n$-heksan : etil asetat (2:8) dan fase diam silika gel $\mathrm{F}_{254}$. Hasil diperoleh menunjukkan bahwa EBB hijau dan merah memiliki kandungan kimia yang sama, 
diantaranya adalah senyawa golongan flavonoid, fenolik dan alkaloid. Hasil ini sesuai dengan penelitian sebelumnya yang menyebutkan bahwa buah buni memiliki kandungan senyawa polifenol dan antioksidan kuat seperti senyawa flavonoid (Butkhup and Samappito, 2011; Hamidu, Ahmad and Najib, 2018). Hasil identifikasi senyawa yang terdapat pada EBB dapat dilihat pada Tabel 2.

Tabel 2. Identifikasi senyawa EBB

\begin{tabular}{llcccc}
\hline No & Buah Buni & Flavonoid & Fenolik & Alkaloid & Saponin \\
\hline 1 & Hijau & + & + & + & - \\
2 & Merah & + & + & + & - \\
\hline
\end{tabular}

Keterangan: $(+)=$ positif; $(-)=$ negatif

Ekstrak buah buni selanjutnya di uji aktivitas penghambatannya terhadap enzim $\alpha$ glukosidase. Pengujian dilakukan dengan mengukur absorbansi enzim $\alpha$-glukosidase dengan menggunakan ELISA, kemudian dihitung $\mathrm{IC}_{50}$ dari masing-masing ekstrak. Alat ELISA dipilih karena volume larutan yang digunakan lebih sedikit dan efisien. Selain itu, beberapa sampel dapat diukur bersamaan dalam satu kali pengukuran, sehingga waktu dan volume larutan lebih sedikit.
Dalam pengujian, $\mathrm{pH}$ optimum yang digunakan untuk analisis enzim adalah $\mathrm{pH} 6,8$, sedangkan suhu optimum untuk enzim adalah $37^{\circ} \mathrm{C}$ (mauldina). Larutan uji terdiri dari beberapa reagen seperti DMSO, dapar fosfat, subsrat $p$-nitrofenil- $\alpha$ D-Glukopiranosid ( $p$ NPG), enzim $\alpha$-glukosidase, $\mathrm{Na}_{2} \mathrm{CO}_{3}$. Substrat pNPG ketika direaksikan dengan enzim akan menghasilkan $p$-nitrofenol (Gambar 1) yang berwarna kuning dalam larutan alkali (Wilson and Walker, 2010).

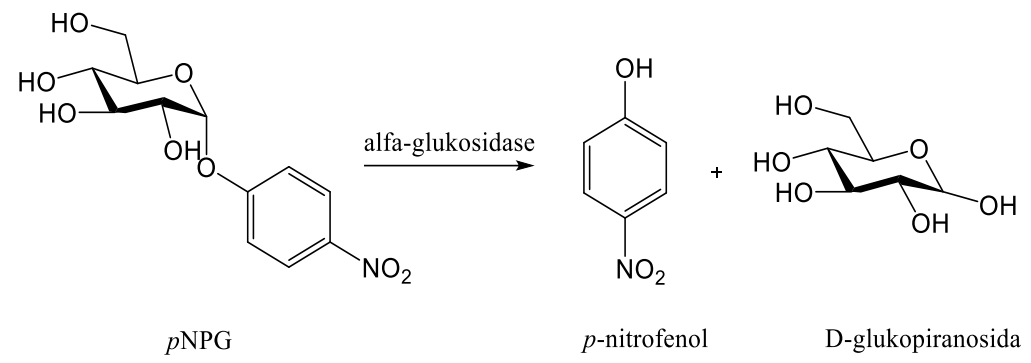

Gambar 1. Reaksi enzimatis $\alpha$-glukosidase dan $p$-nitrofenol- $\alpha$-D-glukopiranosida (Qurrat-ul-Ain et al., 2015)

Aktivitas enzim diukur berdasarkan hasil pengukuran absorbansi dari $p$-nitrofenol. $\mathrm{Na}_{2} \mathrm{CO}_{3}$ berperan untuk menghentikan reaksi enzim, selain itu $\mathrm{Na}_{2} \mathrm{CO}_{3}$ mampu meningkatkan $\mathrm{pH}$ larutan uji hingga $\mathrm{pH} 12$, sehingga enzim akan terdenaturasi pada $\mathrm{pH}$ basa tersebut.

Tabel 3. Nilai $\mathrm{IC}_{50}$ ekstrak buah buni

\begin{tabular}{lll} 
No & Larutan Uji & $\begin{array}{l}\text { IC } \mathbf{5 0} \\
(\mathbf{p p m})\end{array}$ \\
\hline 1 & EBB Hijau & 91,59 \\
2 & EBB Merah & 85,27 \\
\hline
\end{tabular}

Hasil pengujian aktivitas penghambatan enzim $\alpha$-glukosidase dari ekstrak buah buni dapat dilihat pada Tabel 3. Hasil yang diperoleh, ekstrak yang paling aktif adalah EBB merah dengan nilai $\mathrm{IC}_{50}$ sebesar 85,27 ppm. Nilai $\mathrm{IC}_{50}$ dari EBB hijau, tidak memiliki perbedaan yang signifikan. Hasil pengujian penghambatan enzim $\alpha$-glukosidase menunjukkan bahwa EBB memiliki potensi sebagai inhibitor $\alpha$-glukosidase. Aktivitas tersebut kemungkinan di sebabkan karena kandungan senyawa polifenol dan antioksidan kuat yang terdapat pada buah buni seperti senyawa flavonoid.
Reddy mengungkapkan bahwa, efek menguntungkan dari flavonoid telah dipelajai dalam kaitannya dengan DM, baik melalui penghambatan enzim $\alpha$-glukosidase usus atau melalui kemampuannya untuk mencegah penyerapan glukosa dan/atau memperbaiki toleransi glukosa (Reddy et al., 2012)..

\section{Kesimpulan}

Ekstrak buah buni (EBB) merah memiliki aktivitas tertinggi dalam menghambat enzim $\alpha$ glukosidase dengan nilai $\mathrm{IC}_{50}$ sebesar $85,27 \mathrm{ppm}$ dibandingkan EBB hijau.

\section{Conflict of Interest}

Penulis menyatakan tidak ada konflik kepentingan.

\section{Daftar Pustaka}

Ayepola, O. R., Brooks, N. L. and Oguntibeju, O. O. (no date) 'Oxidative Stress and Diabetic Complications: The Role of Antioxidant Vitamins and Flavonoids' doi: 10.5772/57282.

Badan Penelitian dan Pengembangan Kesehatan (2013) 'Riset Kesehatan Dasar 
(RISKESDAS) 2013', Laporan Nasional 2013, pp. 1-384. doi: 1 Desember 2013.

Bisht, Shradha; Sisodia, S. (2010) 'Diabetes, Dyslipidemia, Antioxidant and status of oxidative stress', International Journal of Research in Ayurveda \& Pharmacy, 1(1), pp. 33-42. doi: 10.7897/2321.

Butkhup, L. and Samappito, S. (2011) 'Changes in Physico-Chemical Properties, Polyphenol Compounds and Antiradical Activity During Development and Ripening of Maoluang (Antidesma bunius L. Spreng) Fruits', Journal of Fruit and Ornamental Plant Research, 19(1), pp. 85-99.

Goldenberg, R. and Punthakee, Z. (2013) 'Definition, Classification and Diagnosis of Diabetes, Prediabetes and Metabolic Syndrome', Canadian Journal of Diabetes, 37(SUPPL.1), pp. 8-11. doi: 10.1016/j.jcjd.2013.01.011.

Hamidu, L., Ahmad, A. R. and Najib, A. (2018) 'Qualitative and quantitative test of total flavonoid buni fruit (Antidesma bunius (L.) Spreng) with UV-Vis spectrophotometry method', Pharmacognosy Journal, 10(1). doi: $10.5530 /$ pj.2018.1.12.

Nugroho, A. E. (2006) 'Animal Models of Diabetes Mellitus: Pathology and Mechanism of Some Diabetogenics', Biodiversitas, Journal of Biological Diversity, 7(4), pp. 378-382. doi: 10.13057/biodiv/d070415.

Oyenihi, A. B. et al. (2014) 'Antioxidant -Rich Natural Products and Diabetes Mellitus', Antioxidant-Antidiabetic Agents and Human Health, pp. 1-29. doi: $10.5772 / 57192$.

Van Quan, N. et al. (2019) 'Antioxidant, $\alpha$-Amylase and $\alpha$-Glucosidase Inhibitory Activities and Potential Constituents of Canarium tramdenum Bark', Molecules, 24(3). doi: 10.3390/molecules24030605.

Qurrat-ul-Ain et al. (2015) 'Alpha-glucosidase and carbonic anhydrase inhibition studies of Pd(II)-hydrazide complexes', Arabian Journal of Chemistry. King Saud University. 10.1016/j.arabjc.2015.02.024.

Reddy, G. A. K. et al. (2012) 'Pharmacology \& Toxicology', 2(1), pp. 23-30.

Samappito, S. and Butkhup, L. (2008) 'An analysis on organic acids contents in ripe fruits of fifteen Mao Luang (Antidesma bunius) cultivars, harvested from dipterocarp forest of Phupan Valley in Northeast Thailand', Pakistan Journal of Biological Sciences, pp. 974-981. doi: 10.3923/pjbs.2008.974.981.

Şendoğdu, N. et al. (2006) 'Antidiabetic and antioxidant effects of Vitis vinifera $L$. leaves in streptozotocin-diabetic rats',
Turkish Journal of Pharmaceutical Sciences, 3(1), pp. 7-17.

Sunarwidhi, A. L., Sudarsono, S. and Nugroho, A. E. (2014) 'Hypoglycemic effect of combination of Azadirachta indica A. Juss. and Gynura procumbens (Lour.) Merr. ethanolic extracts standardized by rutin and quercetin in alloxan-induced hyperglycemic rats', Advanced Pharmaceutical Bulletin, 4(Suppl 2), pp. 613-618. doi: 10.5681/apb.2014.090.

Wilson, K. and Walker, J. (2010) Principles and techniques of biochemistry and molecular biology. 7th edn. Edited by K. Wilson and J. Walker. Cambridge, New York: Cambridge University Press.

Yin, Z. et al. (2014) ' $\alpha$-Glucosidase inhibitors isolated from medicinal plants', Food Science and Human Wellness. Elsevier BV, 3(3-4), pp. 136-174. doi: 10.1016/j.fshw.2014.11.003.

Zatalia, S. R. and Sanusi, H. (2013) 'The role of antioxidants in the pathophysiology, complications, and management of diabetes mellitus.', Acta medica Indonesiana, 45(2), pp. 141-7. Available at:

http://www.ncbi.nlm.nih.gov/pubmed/237 70795 . 